\title{
Die huishouding van God volgens Jakobus: Rolmodelle en vriendskap onderweg na 'n postpatriargale identiteit. ${ }^{1}$
}

\begin{abstract}
The household of God according to James: Role models and friendship on the route to a post-patriarchal identity.

Throughout the ages, clerical structures were developed according to the patriarchal family structure, modelled on examples to be found in the New Testament. Upholding a patriarchal (with the accompanying hierarchy) and hetero-normative way of thinking (with accompanying marginalization) within the community of believers, has the potential to wound, oppress and alienate people from the church. This principle has the implication that establishing a post-patriarchal identity in the household, as well as in the church is potentially a key to mutual transformation and liberation. In this article the friendship-model in the book of James is interpreted through the lens of the example of Jesus. Although first-century friendships must be interpreted within the context of patronship, James presents a further perspective: that people should be appreciated as full partners within the relationships.
\end{abstract}

1.

INLEIDING

Die handelinge van gestuurdes ${ }^{2}$ word deur Pieterse (1993:7), in navolging van Firet (1987:260), omskryf as kommunikatiewe handelinge in diens van die Evangelie. Wat die handelinge van die gestuurdes aan hul medemens kommunikeer, behoort voortdurend gemeet te word aan God se bedoeling met die skepping. In hierdie artikel gaan gepoog word om deur die interpretasie van die vriendskapsmodel in Jakobus 'n basisteorie vir die gemeenskap van gelowiges te formuleer vir vandag se liminale konteks. Die liminale konteks wat veronderstel word, is omskryf deur Castells $(2004)^{3}$ en behels die invloed van globalisasie ${ }^{4}$ en inligtingsmatigheid ${ }^{5}$ op die planeet saam met die verskynsel dat die patriargale gesin in krisis verkeer. Met die draai van die millennium is daar begin om die geldigheid van die patriargale gesinstruktuur te bevraagteken. Die rede vir hierdie verskynsel juis nou, skryf Castells (2004:193-5) toe aan die volgende: Die beskikbaarheid van opleidingsgeleenthede aan vroue en hul toetrede tot die arbeidsmark en die invloed daarvan op die ekonomie. Hiermee saam ook tegnologiese veranderings ten opsigte van voortplanting, wat vroue beheer gee oor wanneer en hoeveel kinders hulle het. Laastens die

1 Hierdie artikel is gebaseer op die skrywer se doktorale proefskrif (Bekker 2010). Prof J.Punt was die medepromotor.

2 Die term "gestuurdes" word verkies bo "gelowiges" omdat dit klem lê op die handelende en kommunikerende aard van gelowiges.

3 Die boek "The Power of Identity: The information age: Economy, Society and Culture," is die tweede volume in 'n reeks van drie werke, deur Manuel Castells, 'n professor in Sosiologie.

4 Die vinnige groei van netwerke tussen rekenaars, nasies en gemeenskappe deur middel van die internet, media, vervoer en telekommunikasie, wat die planeet in een "groot dorp" verander het.

5 Die beskikbaarheid en reproduksie van inligting. 
bewusmakingsprosesse van vroue-strewes ("struggles") deur vrouebewegings en die opkoms van feminisme vanaf 1960. Die krisis waarin die patriargale gesinstruktuur verkeer, versteur die ordelike oordrag van vasgestelde kultuurinhoude van een generasie na die volgende. Hierdie model wat kan dien tot die vorming van ' $n$ postpatriargale-identiteit, is ontwikkel uit die interpretasie van vriendskap in Jakobus, met die voorbeeld van Jesus as agtergrond en Abraham, Ragab, Job en Elia as rolmodelle.

Jenkins (2002) verduidelik dat die sentrum van die Christen-wêreld oor die afgelope eeu verskuif het vanaf die "globale noorde" (onder andere Europa en Noord-Amerika) na die "globale suide" (onder andere Afrika, Asië en Suid-Amerika). Terwyl die Christendom krimp in die globale noorde, brei dit uit in die globale suide (Jenkins 2002:2). Kenmerkend van die suidelike Christendom, volgens Jenkins (:7) is dat die meerderheid van gelowiges van die armste mense in die wêreld is. Daar bestaan 'n duidelike verband tussen armoede en die agteruitgang van die omgewing, soos deur die besoedeling van riviere, mere en oseane, die vernietiging van woude en die verspreiding van siektes (Castells 2004:190). Daar leef vandag byvoorbeeld na raming 16 miljoen vlugtelinge in Afrika. Uit hierdie getal leef die meeste vlugtelinge in SuidAfrika (UN-INSTRAW/United Nations International Research and Training Institute for the Advancement of Women 2008). 80\% van hierdie vlugtelinge is vroue en kinders ${ }^{6}$ (UNFPA/United Nations Population Fund 1999).

'n Tweede kenmerk van die kerk van die globale suide is dat die leer en waardes van hierdie kerke konserwatief is (Jenkins 2002:8). Al speel vroue 'n deurslaggewende rol in die groei van die kerk in die suide, is die teologie ten opsigte van genderrolle konserwatief - veral in Afrika (:199). Die kans dat die bevrydende verstaan van gender en seksualiteit (met verwysing na gaygestuurdes) aanvaar sal word in die globale suide, is skraal, omdat hierdie oortuigings as rede aangevoer word waarom kerke in Europa en Noord-Amerika kwyn (:201). Ook in die samelewing as geheel word vroue steeds onderdruk, al word wetgewing wat gelykheid bevorder, op die oppervlak toegepas. Geweld teen en misbruik van die vroulike liggaam kom onder andere na vore as prominente wyses van onderdrukking (Isherwood \& Stuart 1998:15). Solank as wat die mens op aarde bestaan, sal mag deurslaggewend wees in die wyse waarop die samelewing funksioneer. Veral toegekende mag in die patriargale huishouding (deur hiërargiese toegekende "plekke") en kerkstrukture behoort bevraagteken te word.

In die blanke en bruin bevolkingsgroepe in Suid-Afrika kwyn die assosiasie met die Christelike geloof. ${ }^{7}$ In Mead (1994:16) se nadenke oor die rede vir die afname in kerklidmaat getalle in Noord-Amerika (as deel van die kerk van die globale noorde), is die bepalende faktor nie opgesluit in wat die kerk doen of nie doen nie. Die rede blyk eerder die karakter van die kultuur binne gemeentes te wees. Kerklike strukture wat deur die eeue aan die hand van die patriargale gesin ontwikkel het, ${ }^{8}$ het 'n emosionele klimaat gevorm wat nie die mens van vandag se behoeftes

6 Volgens statistiek van "the Office of the United Nations High Commissioner for Refugees."

7 Die NG-Kerk vorm volgens Hendriks (2003) meer as 90\% van die Gereformeerde kerkgroepe. Oor die laaste 20 jaar het feitlik 'n half miljoen blanke lidmate oorgeskuif na Pinkster- en Nuwe Onafhanklike kerke. Dieselfde tendens kom ook binne die bruin bevolkingsgroep voor.

8 Augustinus het byvoorbeeld geglo dat die vrou alleen die beeld van God weerspieël indien sy aan die man, as haar hoof, verbind is. Hierteenoor kon die man op sy eie die beeld van God verteenwoordig. Die oortuiging was ook gehandhaaf dat net mans Christus kon verteenwoordig binne die geloofsgemeenskap en daarom is net mans toegelaat om priesters te word (Radford Ruether 1989:32). Brock (1988:43), Sawyer (1996:66), Nakawombe (1996:43-44), Kanyoro (1996:150) en Woodhead (2003:103) is oortuig dat patriargale hiërargie 'n dominante kenmerk van die Christelike geloof is. Paulus hanteer die huishouding (oikos) as sentraal binne die eerste gemeentes (Hand 16:15, 18:8, 1 Kor 1:16, 16:15, ensomeer) (Dunn 1996:55). Vroeë Christenskrywers, soos die skrywers van die briewe aan Timoteus en Titus, gebruik die huishouding as model vir die kerkstruktuur (Martin 2006:35). Dit behels onder meer 
aanspreek nie (Mead 1994:97). Die wyse waarop die gemeenskap van gelowiges in Jakobus uitgebeeld word, mag moontlik 'n bydrae lewer tot die vorming van 'n postpatriargale identiteit in die kerk en huishouding. ${ }^{9}$

Hoewel die boek Jakobus deur die eeue nie deur almal as belangrik geag is nie, ${ }^{10}$ is die boodskap van Jakobus vir hierdie konteks relevant, omdat hy 'n dringende waarskuwing rig aan gestuurdes wat hulself aan onderdrukking skuldig maak. ${ }^{11} \mathrm{Hy}$ skryf verder aan mense wat reeds tot geloof gekom het, om hulle te herinner dat hulle dade in ooreenstemming met hul geloof moet wees. Brown (1997:730) omskryf die hoorders as gestuurdes wat na die onafwendbare institusionalisering van die geloofsgemeenskap aan hul roeping herinner moes word. Daar is geen eenstemmigheid oor die outeur ${ }^{12}$ of plek van oorsprong vir die boek Jakobus nie. Die teks behoort egter deurgaans gelees te word met die bewussyn dat dit uit ' $n$ patriargale agtergrond kom. ${ }^{13}$ Daar behoort wel daarna gestreef te word om die bevrydende en helende God-geïnspireerde boodskap daarvan aan vroue én mans te ontgin.

Die geadresseerdes van die boodskap is "die twaalf stamme wat oor die wêreld versprei is" (Jak 1:1). Hier maak Jakobus gebruik van die beeld van die twaalf stamme van Israel wat as swerwende volk tussen ander nasies moes woon. Waarskynlik het die hoorders van hierdie brief hulself in soortgelyke omstandighede bevind (Tamez 1994:383). Vroeg in die eerste eeu is die Christene van Jerusalem vervolg en moes hulle vlug (volgens Hand 8:1). Die eerste lesers van Jakobus was daarom waarskynlik gemeenteleiers wat aan hoof van 'n huisgemeente gestaan het (Scaer 1983:35). Die ontvangers is arm en word onderdruk (Jak 5:1-11). ${ }^{14}$ Tog is daar sprake van ryk gelowiges in hul midde (Jak 1:10 en 4:13-17). Ryk landhere het werkers geëksploiteer

Aristoteles se huishoudelike teorie: die heers van keiser oor onderdane, eienaar oor slaaf, man oor vrou en pa oor kinders (Dunn 1996:49). Die sogenaamde "huishoudelike kodes" soos vervat in Efesiërs 5 en 6 is 'n voorbeeld hiervan (Grobbelaar 2008:361).

9 Die huishouding is belangrik omdat die primêre verhoudings in die huishouding alle latere verhoudings beïnvloed (Baron en Bryne 2000:305).

10 Met die samevoeging van die Kanonieke boeke, was Jakobus aanvanklik op sommige lyste weggelaat (Byvoorbeeld die sinode van Nicea 325 nC) (Painter 1999:235). Eers aan die einde van die vierde eeu is Jakobus as deel van die Kanon aanvaar (Tamez 2002:2). Die nalatenskap van Martin Luther in 1522 (Martin 1988:cv) dra by tot die miskende potensiaal van die boek. Luther het die boodskap van Jakobus gekritiseer omdat die kruisiging en opstanding van Christus nie direk verkondig word nie, en noem Jakobus die "epistel van strooi."

11 Sy geskrif is dié boek in die Nuwe Testament wat die duidelikste die uitsprake teen onderdrukking, soos gevind in Eksodus, weergee (Hanks 2000:201).

12 Die waarskynlikste outeur van die boek is Jakobus, broer van Jesus (Kotzé 1990:6), maar die dokument is moontlik later deur 'n ander outeur geredigeer (Tamez 1994:382).

13 Duidelike tekens bestaan dat Jakobus binne 'n patriargale samelewing geskryf is. Vroue word nie pertinent genoem nie, omdat hulle nie as selfstandige individue hanteer is nie. Daar word byvoorbeeld na die mensheid verwys as man (anér) in Jak 1:8 en 12 en 3:2 (Tamez 2002: 20-21). Jakobus spreek sy gehoor aan as "broers" (Jak 1:2; 2:1,14; 3:1,10,12; 4:11; 5:7, 9, 10, 12, 19) en geliefde broers (Jak $1: 16 \& 19 ; 2: 5)$. Die gebruik van broer of suster in Jakobus $2: 15$ is nie bedoel as inklusiewe taal nie, maar lê eerder klem op die armoede van veral vroue. Hy gebruik die Ou Testamentiese beeld van 'n huwelik tussen God en mens en noem 'n ongehoorsame gestuurde 'n egbreekster (Jak 4:4), bloot omdat dit by hierdie metafoor inpas (Tamez 1994:384). Wolmarans (1994:39) verstaan selfs hierdie beeld as die voortsetting van patriargale denke deurdat die vrou as gevaarlik getipeer word.

14 Hierdie sosio-ekonomiese omstandighede pas by die konteks van eerste-eeuse Palestina, maar was ook toepaslik deur die hele Romeinse ryk. Dit is wel duidelik dat Jakobus in 'n Joods-Christelike konteks hoort (Chester 1994:14). 
en vroue was die armste van die armes. Jakobus se boodskap spreek die probleme aan wat ontstaan het in sy gemeenskap as gevolg van hierdie omstandighede (Moo 2002:89).

Die voorbeeld van Jesus wat die interpretasie van Jakobus beïnvloed het, kan as volg omskryf word: Stuart (1997:45) verwys na die wyse waarop Jesus mense uit die hiërargiese strukture van die familie en huwelik geroep het om 'n nuwe verstaan van familie te vorm, wat op vriendskap gebaseer is. Van die begin af identifiseer Jesus nie met sy bloedfamilie op 'n wyse kenmerkend aan die eerste eeuse konteks nie. Wanneer Sy ouers na afloop van hul besoek aan Jerusalem Hom (na drie dae) in die tempel vind, antwoord Hy (Luk 2:41-49): "Waarom het u my gesoek? Het u nie geweet dat ek in die huis van my Vader moet wees nie?" Jesus verlaat sy huishouding en moedig mans en vroue (Luk 8:1-3) aan om ook hul huishoudings te verlaat en daarmee saam hul identiteit (Punt 2005:13). Wanneer Sy moeder en broers en susters Hom laat roep sê Hy (Mark 3:31-35): "Elkeen wat die wil van God doen, is my broer en my suster en my moeder." Dit handel hier oor diegene wat Sy roeping wil strem, en diegene wat dit bevorder. Jesus antwoord 'n dissipel dat die dooies hul eie dooies moet begrawe (Matt 8:22). Hierdeur verwerp hy nie die biologiese familie nie, maar enige verhouding of verantwoordelikheid wat tussen die individu en die mens se verantwoordelikheid teenoor die hele mensheid staan. Die huishouding (oikos) staan ondergeskik aan die huishouding van God (ekklesia) (Breidenthal 1997:6). Die huishouding word eerder ' $n$ versorgende ruimte wat elkeen toelaat om hul volle potensiaal uit te leef en medeverantwoordelikheid te kan neem vir God se herskepping.

Tog hou Hy nie op om in huishoudelike terme te praat nie (Moxnes 2003:6). Die hoof van die "koninkryk" in Matteus, is nie 'n koning nie, maar 'n Vader (Matt 13:43). Die groep wat rondom Jesus versamel, ontvang 'n identiteit as familie van God wat die wil van God doen (Matt 12:4850). Jesus verwys na Sy volgelinge in huishoudelike terme: broer, suster, moeder (Markus 10:2930) - maar nie as vader of vrou nie. Daar is by Hom geen aanduiding van hiërargie, voortplanting of patriargie in Sy familie nie (Russel 1987:24). Hy verwys na hulle as vriende (Joh 15:13-15). Hier kom "dieselfde in opinie" na vore, omdat die dissipels Jesus gehoorsaam, nie as dienaars nie, maar omdat hulle Jesus se hart ken (Johnson 2004b:161). Dit verander die gesindheid waarmee Sy volgelinge Sy wil uitvoer, van verpligting na vrywillige keuse. Met hierdie ingesteldheid sal die hedendaagse mens kan identifiseer.

Jakobus spreek ook die ekklesia eerder as die oikos aan. Dit gaan vir hom meer oor gestuurdes wat handel op grond van hulle geloof, as die gestuurde se plek in die samelewing. Verseput (2000:104) wys op die duidelike onderskeid tussen ander Joodse diatribe-tipe geskrifte van die eerste eeu en Jakobus. Waar ander geskrifte aan ' $n$ familiale opset gerig is, skryf Jakobus oor kommunale sake soos spraak, leierskap en die behandeling van armes by samekomste (Jak 2:113). Jakobus verwys na ekklesia wanneer hy mense onderrig byvoorbeeld in Jakobus 2:2 en 5:14. Hy gee instruksies aan ouderlinge en onderwysers in Jakobus 3:1 en 5:13. Jakobus gee geen aandag aan die huwelik of aanmoediging tot konformering met sosiale instellings, soos feitlik al die wysheidsliteratuur van sy tyd gedoen het nie. Die aandag aan die huwelik binne Jakobus se samelewing sou slegs gedien het om vroue as onderdanig teenoor mans te posisioneer en terug te plaas binne die oikos (en dus die privaatsfeer). Vir Jakobus is vroue nie 'n "probleem" wat onder manlike beheer hoort nie en hy maak ook nie onderskeid tussen publiek en privaat nie (Johnson 2004a:110). Vroue kan behoeftig wees net soos mans (Jak 2:14) en hulle kan gehoorsaam wees net soos mans (Jak 2:25). Deur te fokus op geloof wat in dade oorgaan, maak hy nadenke oor vroue in terme van ordentlikheid en onderdanigheid irrelevant (Cargal 2004:112).

Jakobus toon sterk ooreenkomste met wysheidsliteratuur uit die Ou Testament en die 
tussentestamentiese tyd ${ }^{15}$ (Evans 2002:775). Jakobus se styl kom ooreen met wysheidsliteratuur wat praktiese raad en onderrig gee sodat die hoorders sal weet wat om te doen in 'n gegewe situasie en die regte pad te volg en kwaad te vermy (Chester 1994:9). Antieke wysheidsliteratuur het baie duidelik beskryf hoe die leser sy/haar "voorgeskrewe plek" in die wêreld kan behou deur die motivering van eer en skaamte. ${ }^{16} \mathrm{Om}$ te konformeer met die algemeen geldende reëls van die samelewing is eervol. Jakobus se opdrag om alle mense as gelykes te hanteer (Jak 2:4, 9; 4:6-10, 11-12), is teenstrydig met die konteks se eer en skaamte-riglyne (Wachob 2000:198). Om onbesmet van die wêreld te bly (Jak 1:27), dui op rituele reinheid en verwys na 'n weiering om die waardes van die wêreld wat hierdie lyding veroorsaak, te aanvaar (Tamez 1994:386). Hy ondergrawe die rangordes van sy tyd byvoorbeeld: Oud/jonk, vry/slaaf, mans/vroue, ryk/arm, leermeester/leerder en plaas wysheid binne bereik van alle mense (Jak 1:5). Hy verwys ook nie na die verskillende generasies soos gevind was in die tradisionele huishouding nie. God is die enigste gesag waaraan gelowiges moet gehoor gee.

In Joodse etiese tradisies was daar dikwels verwys na twee weë: die slegte en die goeie, as teenoorgesteldes. Jakobus werk ook met twee weë naamlik vriendskap met God en vriendskap met die wêreld (Jak 2:23, 4:4). Deur die verskeidenheid temas in die boek as onderdeel van hierdie twee weë te verstaan, kan bydra tot die verstaan van die boodskap van die geskrif. Vriendskap met die wêreld word gekenmerk deur aardse wysheid wat naywer en selfsug tot gevolg het (Jak 3:14-16). Sulke mense streef die hele tyd om hulself te verryk en veroorsaak wanorde en allerhande gemene dade, stryd en rusie (Jak 3:14; 4:1-3). Vir Jakobus begin boosheid by menslike begeerte na dinge, weens 'n gevoel van onvoltooidheid (Jak 1:4). Wanneer die mens verlei word deur sy/haar eie begeertes, ontwikkel die boosheid en gee dan geboorte aan sonde en die dood (Jak 1:15) (Rhoads 1998:476). Jakobus se uitsprake behoort verstaan te word teen die agtergrond dat die eerste-eeuse mens die wêreld as beperk beskou het (beperkte mag, beperkte eer, beperkte besittings ensovoorts). Hulle sou byvoorbeeld nie net iets soortgelyk as iemand anders begeer het nie, maar sou die spesifieke besitting van die ander wou wegneem. Dit het baie jaloesie en kompetisie in die samelewing veroorsaak. Jakobus wys op twee sondes wat hieruit voortkom: sonde deur woorde, byvoorbeeld die vloek van mense wat as die beeld van God gemaak is (Jak 3:9-10), kwaadpraat van ander (Jak 4:11), en sonde deur dade, byvoorbeeld deur armes met minagting te behandel (Jak 2:6) en die ryke bevoordeel (Jak 2:9), stryd en rusie (Jak 4:1-2) (Rhoads 1998:477). Hierdie sonde bring verdeeldheid en onrus in die gemeenskap.

Teenoor vriendskap met die wêreld stel Jakobus vriendskap met God voor. Wanneer mense na heelheid soek, moet hulle vir God om wysheid vra (Jak 1:5). Die wysheid wat van God kom is sonder bybedoelings, vredeliewend, inskiklik, bedagsaam, vol medelye en goeie vrugte, onpartydig en opreg (Jak 3:17). Weer volg 'n geboorte: deur God. God se goeie gawes is onbeperk (Jak 1:17). Daar is geen rede vir kompetisie nie (Rhoads 1998:179). Ook ten opsigte van vriendskap met God, is woord en daad belangrik (Jak 2:12). Vriendskap met God bring voltooidheid (Jak 1:4) en laat ruimte dat mense hulle volle potensiaal bereik (Jak 3:18) (omdat onderdrukking onnodig sou wees). God gebruik die gemeenskap (en nie die huishouding alleen nie) om in mekaar se behoeftes te voorsien (Jak 1:27) (:481). Dit bring harmonie in die gemeenskap (Jak 3:17). Hiervolgens som Rhoads (:485) die boodskap van Jakobus op as, dat vriendskap met God sal lei tot woord en daad wat harmonie in die gemeenskap sal bewerk. ${ }^{17}$

15 'n Goeie voorbeeld uit hierdie periode is die boek van Sirag (Theissen 2003:91).

16 In die eerste eeu was eer ("honour") 'n persoon se aanspraak om waarde en publieke erkenning wanneer onder andere gepas binne sekere grense gehandel word. Die drie grense is: mag, geslag en "godsdiens"

(Malina 1993:30). Skaamte ("shame") daarteenoor, is onder andere, die ignoreer van sosiale grense (:39).

17 Binne hierdie konteks was die deelwees van die groep as baie belangrik beskou. Malina et al (1995:19) interpreteer Jakobus 4:11 in hierdie lig: Deur nie vir jou broer kwaad te raak nie dien die beskerming van groepsgrense. 
Die wyse waarop Jakobus sy boodskap aanbied, laat oral suggesties dat hy die verhouding tussen God en mens as vriendskapsverhouding tipeer. ${ }^{18}$ Hierdie verhouding dien as model van verhoudings tussen gestuurdes. ${ }^{19}$ Vriendskap het by implikasie die hoorders se hele lewe geraak, aangesien vriendskapsverhoudings deel van die individu se privaat en publieke lewe beskou is (O’Day 2004:147). Vriende was binne hierdie konteks as deel van die uitgebreide familie beskou (Malina et al 1995:25).

4. ROLMODELLE IN JAKOBUS VIR DIE POST-PATRIARGALE HUISHOUDINGS

Die persone uit die Ou Testament wat in Jakobus as vriende van God voorgehou word, naamlik Abraham (Jak 2:21), Ragab (Jak 2:25), Job (Jak 5:11) en Elia (Jak 5:17) kan as rolmodelle dien in die nadenke oor die vriendskapsverhouding in die huishouding en kerk.

Die aksie waarna spesifiek in Jakobus 2:21 verwys word, is Abraham se gewilligheid om sy seun te offer (Gen 22). Abraham word hiervoor 'n vriend van God genoem (2 Kron 20:7 en Jak 2:23). Abraham is vriend van God omdat hy in geloof en ondubbelhartige toewyding geleef het en daarvolgens gehandel het. Hierdie optrede getuig nie van 'n persoon wat voortdurend in beheer moet wees nie, maar eerder van iemand wat bereid is om met onsekerhede saam te leef.

Abraham het ook dikwels opgetree binne die patriargale denkraamwerk van sy tyd. By twee geleenthede lewer Abraham vir Sara uit aan vreemdes om sy eie lewe te spaar en hy handhaaf die tradisie dat vroue nie saam met mans eet nie (Gen 18:8-9). Tog het Abraham dikwels vir Sara as gelyke gespreksgenoot en onafhanklike besluitnemer hanteer (Gen 16:2; 16:6; 21:8-10). Sara word deurgaans uitgebeeld as sterk vrou met ' $n$ eie opinie, sy het daadwerklike besluite geneem en het dit dan gekommunikeer (Gen 16:2-6; 18:10-12; 21:6-12). Ook in terme van seksualiteit verskil Abraham en Sara se verhouding van die algemeen-geldende deurdat Sara seks met genot assosieer (Gen 18:12).

Vir die moderne leser kan dit verblydend wees dat Jakobus vir Abraham en Ragab albei as modelle van geloof voorhou, omdat dit die indruk van gelykwaardigheid skep. Jakobus verbind egter juis die name van Abraham en Ragab om kontras weer te gee (Kistemaker 1986:99). ${ }^{20}$ Die feit dat Ragab as prostituut benoem word, tipeer haar volgens Humphries-Brooks (2001:140) as 'n kommoditeit - soos vroueliggame dikwels ook vandag gesien word. In die Joodse tradisie, was 'n prostituut ' $n$ veragte (Levitikus 19:29; 21:7\&14) - iemand sonder wysheid, godsdienstige

18 Hoewel Jakobus nie sê dat die mens en God "een in siel" is nie, verwys hy wel na die dubbelhartiges en die onstabiele mens (Batten 2008:266). Wanneer God byvoorbeeld in Jakobus 1:5 "sonder voorbehoud en sonder verwyt" gee, staan dit in ooreenkoms met hoe vriendskap in die eerste-eeuse Hellenistiese en Romeinse konteks verstaan is. ' $n$ Vriend is verstaan as iemand wat met eerlikheid en eenvoud gepraat en gegee het (:265). Die toets van 'n ander is as kenmerk van vriendskap verstaan en word na verwys in die boek. Abraham en Job het as vriende van God, 'n toets deurstaan. So word ootmoed/nederigheid (Jakobus $1: 21$ en 3:13) ook met vriendskap geassosieer, met jaloesie as teendeel (:266-7).

19 Die model wat volgens verskeie feministe (onder andere Heyward 1989, Hunt 1991, Stuart 1995) die grootste potensiaal het om die strewe na gesonde verhoudinge te beliggaam, is vriendskap. Hulle kies vriendskap om onder meer die volgende redes: Vriendskap is inklusief en gebaseer op gelykwaardigheid en in die Westerse tradisie is vriendskap 'n verhouding wat geen suggestie ten opsigte van seksualiteit het nie (Isherwood \& Stuart 1998:105). Nieteenstaande die ongebalanseerdheid van eerste-eeuse vriendskapsverhoudings soos meegebring deur die weldoenersisteem, is vriendskap die een gelykwaardige verhouding waarmee die moderne mens sal kan identifiseer en wat verdeeldheid sal kan herstel.

20 Die beskrywings wat Jakobus vir sy manlike helde gebruik, gee 'n aanduiding van 'n ereplek in die tradisie van die Torah. Abraham word "ons voorvader" genoem (Jak 2:21) en 'n vriend van God (Jak 2:23). Job word verbind aan profete (Jakobus 5:10). Elia word 'n gelowige genoem (Jak 5:16-17). In kontras word Ragab net as prostituut omskryf (Johnson 2004a:105). 
kennis of waardes (Bird 1997:214). Sy word as gemarginaliseerde voorgehou. ${ }^{21}$ God lig haar egter uit die posisie as veragte objek tot handelende subjek (Bird 1997:213).

Voor die intog in die Beloofde land, gaan twee verkenners tuis by Ragab. Sy ontvang hulle gasvry in haar huis. Ragab neem beheer van die situasie en neem besluite namens haar familie. Sy waag haar lewe deur die twee mans weg te steek en die koning te mislei en stel voor dat hy "gou [maak] en [hulle] agtervolg" - wat die koning toe doen (Jos 2:5\&7). Sy gee aan die verspieders strategiese raad (Jos 2:16), voer 'n teologiese gesprek met hulle (Josua 2:8-11) en gaan met hulle 'n ooreenkoms aan (Jos 2:13). Sy openbaar hierdeur optrede wat in haar konteks tipies van mans verwag is. Haar huishouding verteenwoordig ook 'n nie-tradisionele struktuur, wat herinner aan die huishouding van Marta (Luk 10:38; Joh 11:1). As hoof van 'n huishouding en eienaar van ' $n$ besigheid (Bird 1997:211), het sy ook haar ouers in haar sorg. Sy staan in die rol van patriarg binne die Joodse tradisie (Humphries-Brooks 2001:141). In Hebreërs 11:31 word haar geloof saam met dié van onder andere Henog, Noag, Abraham, Jakob en Josef genoem.

Van beide Abraham en Ragab word gesê dat hulle vrygespreek is op grond van hul dade (Jak $2: 21,24-25)$. Abraham en Ragab se handelinge was albei gekenmerk deur gasvryheid. ${ }^{22}$ Dit is gehoorsaamheid wat hierdie twee op die ou end gelykes maak (Kistemaker 1986:100).

Job bevind homself in ' $n$ maglose en liminale posisie, in skrille kontras met sy patriargale posisie van vroeër. Hy word gemarginaliseer en ly onskuldig, net soos vroue wat ly, net omdat hulle vroue is (Tamez 1994:387). Job se verhaal word in hierdie opsig in metaforiese terme as rolmodel gebruik. Die ideale liggaam in antieke Israel is verteenwoordig deur ' $n$ rein en heel liggaam wat binne sekere grense funksioneer (Lev 12-15). Slegs heel liggame - sonder gebreke of "materie uit plek" 23 - is toegelaat binne familieverhoudinge. Job se sieklike liggaam (Job 7:5; 30:30) het die ordelike samelewing versteur, en daarom word hy uit die samelewing gesluit (Basson 2008:288). In hierdie familie-gebaseerde samelewing was oorlewing buite die samelewing feitlik onmoontlik en gelykstaande aan 'n sosiale dood: sonder regte, status, beskerming of identiteit. As gevolg van sy sieklike liggaam word Job verwerp en gemarginaliseer en as gevaarlik beskou (:294). ${ }^{24}$

Wanneer God uit die stormwind met Job praat, troos hy hom nie. Hy neem hom na die skepping. In alles wat hy gesien het, sien hy nie een mens nie. Dale (aangehaal deur Habel 2001b:185) beskou hierdie aksie as 'n desentralisasie van die skepping. Die mens is nie die middelpunt van die skepping nie. God vra: verstaan jy wat jy sien? En: Kan jy dit beheer? Die skeppingsverhaal is dus nie normatief nie. Job 38 bied 'n ander perspektief op die skeppingsgebeure. Job vertel van 'n skepping-gesentreerde teologie.

Job sinspeel dat die aarde sy moeder is in Job 1:21. Die aarde is sy tuiste, sy ma, sy familie (Habel 2001a:66). Job 38 hou die aarde voor as huishouding wat deur God bestuur word. Hierdie

21 Haar huis is letterlik op die grens van die stad "in die muur" (Jos 2:15) - 'n liminale posisie. Hierdie afleiding kan gemaak word, omdat antieke stede hiërargies uitgelê is, met die koning se paleis en die tempel in die sentrum. Vanaf die sentrum na die buitewyke van die stad, sou 'n progressiewe daling in rykdom en status na vore kom (Humphries-Brooks 2001:140).

22 Abraham se gasvryheid spreek uit sy optrede wanneer hy drie besoekers naby sy tent sien staan. Hy draf nader en nooi hulle in. Hy berei 'n maaltyd voor (hopeloos te veel vir drie gaste) en stap 'n ent saam met hulle, met hulle vertrek (Gen18:1-16). Hierdie verhaal staan in kontras met die ongasvryheid van Sodom en Gomorra (Gen 19:1-11), wat ook daarvoor bekend was dat hulle armes onderdruk het (Esegiël 16:4649).

23 Reinheidswette volgens Malina (1993:153) het te doen gehad met materie (soos menstruasie) of mense "uit hul plek uit." Om uit plek te wees, veronderstel orde en grense. (Gebaseer op die teorie van Douglas (1966).

24 'n Posisie waarmee vroue kan identifiseer, onder andere deur tendense soos skuldgevoelens by vroue nadat hulle verkrag is, die van vrouebesnydenis en vroue wat ly as gevolg van obstetriese fistula. 
huishouding het plek vir alle gediertes (:75) - sonder hiërargie. Job plaas die huishouding waarvan hy deel is, as onderdeel van die skepping. Hierdeur word die grense tussen huishouding (oikos), die ekklesia en die kosmos verdof. Die skepping is die gestuurde se verantwoordelikheid, want soos McFague (1993:165) dit stel: "Nature is the 'new poor'..."

Ook Elia se optrede wys God uit as ware natuur-God teenoor die vals natuur-god, Baäl. Hy leer God as God van die natuur ken deur Sy/Haar mag oor reën en vuur. Terwyl hy by die Kritspruit skuil, stuur God kraaie om hom te versorg (1 Konings 17:4). Die enigste verwysing wat Jakobus na God as Vader maak, is wanneer hy Hom/Haar die "die Vader wat die hemelligte geskep het" (Jak 1:17) noem. Wanneer so na God as Skepper (Ng 2003:43) verwys word, sluit die huishouding die hele kosmos in.

Elia leef nie'n onafhanklike en selfvoorsienende lewe nie, maar leef in biddende afhanklikheid van God. God reël vir Elia huishoudings waar hy versorg kan word. Hy gaan by ' $n$ weduwee tuis wat hom versorg met middele wat God midde in 'n droogte voorsien (1 Kon 17:9). Ook later met die engel wat hom besoek in die woestyn word 'n huishoudelike prentjie geskep deurdat die engel hom wakker maak om te eet (1 Konings 19:5\&7). Dit impliseer dat gasvryheid ' $n$ kenmerk van die gemeenskap van gelowiges sal wees. Gasvryheid sal vereis dat geen mens sonder huishouding sal wees nie.

In 'n gemeenskap waar armes leef is gasvryheid 'n belangrike waarde. Jakobus identifiseer onderdrukking as fundamentele oorsaak van armoede (Jak 1:9-11; 2:1-13). Hierteen spreek Jakobus hom duidelik uit. Hy bevestig die menswaardigheid van die arme en gemarginaliseerde (Jak $1: 9-11 ; 2: 1-13$ ). Hy moedig die arme aan om geduldig te wees omdat God hulle sal help. Hierdie is egter nie 'n passiewe soort geduld nie, maar ' $n$ strewe om sin te vind binne moeilike omstandighede. Wanneer Jakobus lydende Christene aanmoedig om op die positiewe in hul omstandighede te fokus, is dit ' $n$ uitnodiging tot menswaardigheid, deur nie onder verontmenslikende omstandighede moed op te gee nie (Jak 1:2-3).

Die gedeelde maaltyd as simbool van vriendskap, bied 'n ruimte vir vreugdevolle en inklusiewe saamwees van mense wat van mekaar hou en omsien na mekaar se basiese behoeftes (McFague 1987:172). Dit impliseer verder dat niemand sonder huishouding sal wees nie. Vriende word hierdeur 'n uitgebreide familie. Binne hierdie familie gaan dit oor die gestuurde wat handel en nie oor die plek van die gestuurde in die oikos nie. ${ }^{25}$ Jakobus gee geen aandag aan "plek" nie, en fokus alleen op bevrydende praxis wat uit ondubbelhartige toewyding aan God spruit (Jak 1:7-8; 2:14-26). Hy gee ook geen aandag aan die huwelik nie, en akkommodeer seksuele minderhede (Jak 1:27; 2:25). Hierdie familie (huishouding) word nie beperk deur die grense tussen publiek en privaat nie. So vind die mens sy/haar plek as onderdeel van die skepping met God alleen as hoof. Aan gestuurdes word die ruimte gegun om te individualiseer sonder om tot gegewe rolverwagtings te konformeer (soos gevind in die lewe van Abraham, Ragab, Job en Elia). Dit sal vra dat die kerk daartoe sal streef om veral vroueliggame wat "gekolonialiseer" 26 is, te bevry.

Volgens McFague (1987:167) is die vreugde van saamwees die kern van die model as daar oor die verhouding tussen God en mens as vriendskap gedink word. Carmichael (2004:185) verwys na "the 'unnecessary' nature" van vriendskap, wat dit die mees vrygekose vorm van liefde maak. Dit impliseer volgens haar dat gelowiges nie as slawe van mekaar leef nie maar vrywillig op mekaar se behoeftes kan reageer. Dit maak ' $n$ bestaan van "om saam met ander te wees" moontlik, eerder as om "daar vir ander te wees" (Carmichael 2004:187). Met hierdie verstaan word klem gelê op verhoudings as prioriteit. Vir'n samelewing waar die nood van ander

25 Jakobus gebruik byvoorbeeld die terme "broers en susters" (Jak 2:15) en "vriende van God," (Jak 2:23) eerder as man, vrou, kind of hoof.

26 Deur: vrees vir verkragting, vroueliggame te behandel as kommoditeit, geweld en om van vroue te verwag om alleen die versorging van die huishouding en kinders waar te neem. 
daagliks mense oproep tot hulpverlening, is dit 'n bevrydende vertrekpunt. Dit nooi mense tot verhoudings en nie meganiese betrokkenheid by ander nie. So 'n verstaan sal ook die hiërargie van "gewer" en "ontvanger" vermy. Hierdie soort saamwees bemagtig mense tot individuasie 27 en voorkom ongesonde afhanklikheid. Vir vroue sal dit veral betekenisvol wees omdat dit 'n ruimte sal skep waarbinne hulle hul eie identiteit kan ontdek ten einde medeverantwoordelike medewerkers in God se herskepping te wees. Op die ou end funksioneer individuasie en onafhanklikheid tot voordeel van die gemeenskap. Dit is juis hierdie gevolg wat individuasie van individualisme onderskei, omdat individualisme selfgerig is.

\section{SLOT}

Met hierdie klem op vriendskap tree uitsluitende waardes soos geslag, status en liggaamlikheid nie op die voorgrond nie. Niemand gee seggenskap op hul liggame op nie - ook nie in die huwelik nie. Aan elke mens word ruimte gegun om te individualiseer - ook aan kinders deur ouers. Gasvryheid as sentrale waarde van vriendskap nooi die vreemdeling in tot ' $n$ vreugdevolle saamwees en wedersydse versorging. Vriendskap met God bring voltooidheid en bevry mense van afguns en kompeterende optrede. Heel mense kan in eenvoud leef en op hierdie wyse ruimte laat dat alle lewende wesens genoeg kan hê om van te leef. Die sleutel tot die uitleef van vriendskapsverhoudings, is die afstaan van toegekende mag. Hierdie argument wil bydra tot die vestiging van 'n post-patriargale samelewing en 'n ekofeministiese werklikheidsverstaan ${ }^{28}$ in die kerk (ekklesia) deur'n bewusmakingsproses. ${ }^{29}$ Die vriendskapsbeeld kan huishoudings (oikoi) en die geloofsgemeenskap (ekklesia) bystaan in die proses om toegekende "plekke" af te staan en in nie-hiërargiese verhoudings teenoor mekaar te staan.

\section{BRONNELYS}

Arnold, C.E. (Gen. Ed.) (2002) Zondervan illustrated Bible Backrounds Commentary, Volume 4. Hebrews to Revelation. Zondervan, Grand Rapids, Michigan.

Baron, R.A., Byrne, D. (2000) Social Psychology. Allyn \& Bacon, Massachusetts, VSA.

Barton, S.C. (Ed) (1996) The Family: In Theological Perspective. T\&T Clark, Edinburgh.

Basson, A. (2008) Just Skin and Bones: The Longing for Wholeness of the Body in the Book of Job. Vetus Testamentum 58: 287-299.

Batten, A. (2008) God in the Letter of James: Patron or Benefactor? Neotestamentica. Journal of the New Testament Society of South Africa, 42 (2): 257-271.

Bekker, C. (2010) "Die huishouding van God" as helende en bevrydende ruimte in 'n tydperk van liminaliteit. Die ontwikkeling van 'n teologiese basisteorie. 'n Doktorale Proefskrif in die Praktiese Teologie aan die Universiteit van Stellenbosch.

Bird, A.B. (1997) Missing Persons and Mistaken Identities: Women and Gender in Ancient Israel. Overtures to Biblical Theology. Fortress Press, Minneapolis, VSA.

Breidenthal, T.E. (1997) Christian Household: The Sanctification of nearness. Cowley Publications, Boston,

27 Individuasie is 'n lewenslange groeiproses waardeur die individu tot verstaan van sy/haar unieke identiteit kom (Lemmer 2005:68).

28 Volgens Radford Ruether (2003:24) werk ekofeministe met die uitgangspunt dat daar 'n direkte verband bestaan tussen patriargale kulture oor die algemeen en die onderdrukking van vroue en die natuur. Ekofeministe streef na die bevryding van die natuur en vroue gelyktydig deur 'n skeppinggesentreerde ("earth-honouring") spiritualiteit.

29 Bewusmaking as werkswyse is belangrik omdat mag in die laat modernistiese tydperk geherdefinieer is. Institusies (die staat), organisasies (kapitalistiese maatskappye) of die simboliese heersers (die kerk) beskik nie meer oor deurslaggewende mag nie. Die nuwe mag is opgesluit in inligtingsmatigheid en word gevind in die denke van mense. Dit wat die mens se denke kan beïnvloed, sal oor mag beskik (Castells 2004:425). 
V.S.A.

Brock, R.N. (1988) Journeys by Heart: A Christology of Erotic Power. The Crossroad Publiching company, New York, VSA.

Brown, R.E. (1997) An introduction to the New Testament. Doubleday, New York.

Campbell, D.A. (Ed) (2003) Gospel and Gender: A Trinitarian Engagement with being Male and Female. T\&T Clark International, London.

Cargal, T.B. (2004) When Is a Prostitute Not an Adulteress? The Language of Sexual Infidelity in the Rhetoric of the Letter of James. (Levine 2004:BI.114-126).

Carlson-Brown, J., Bohn, C.R. (Eds) (1989) Christianity, Patriarchy and Abuse: A Feminist Critique. The Pilgrim Press, New York.

Carmichael, L. (2004) Friendship: Interpreting Christian Love. T\&T Clark International, New York, VSA.

Castells, M. (2004) The Information Age: Economy, Society, and Culture. Volume II. The Power of Identity. Blackwell Publishing, VSA.

Clark Kroeger, C., Evans, M.J. (Eds) (2002) The IVP Women's Bible Commentary. InterVarsityPress, Illinois.

Chester, A. (1994) The Theology of James. (Chester \& Martin 1994:Bl.1-62).

Chester, A., Martin, R.P. (Eds) (1994) The Theology of the Letters of James, Peter, and Jude. Cambridge University Press, Cambridge.

Cosslett, T., Easton, A., Summerfield, P. (Eds) (1996) Women Power and Resistance: An Introduction to Women's Studies. Open University Press. Buckingham.

Douglas, M. (1966) Purity and danger: an analysis of concepts of pollution and taboo. Routledge \& Paul, London.

Dunn, J.D.G. (1996) The Household Rules in the New Testament. (Barton 1996:BI.43-64)

Evans, M.J. (2002) James. (Clark Kroeger \& Evans 2002:BI.775-779).

Firet, J. (1987) Spreken als een leerling: praktisch-theologische opstellen. Kok, Kampen.

Grobbelaar, J. (2008) 'n Ondersoek na die bediening van Laerskoolkinders in en deur die gemeente as intergenerasionele ruimte. 'n Doktorale Proefskrif in die Praktiese Teologie aan die Universiteit van Stellenbosch.

Habel, N.C. (2001a) Earth First: Inverse Cosmology in Job. (Habel \& Wurst 2001:Bl.65-77b).

Habel, N.C. (2001b) Is the Wild Ox Willing to serve you? (Habel \& Wurst 2001:BI.179-189).

Habel, N.C., Wurst, S. (Eds) (2001) The Earth Story in Wisdom Traditions. Sheffield Academic Press, Sheffield, Engeland.

Hanks, T. (2000) The Subversive Gospel. A New Testament Commentary of Liberation. The Pilgrim Press, Cleveland, Ohio.

Hendriks, H.J. (2003) Die toekoms van die kerk, die kerk van die toekoms. Artikel geplaas op die GDA (Gemeente Dienste Netwerk). Afgelaai van die internet 21 November 2008. http://www.gemeentes. co.za/Pdf/Die\%20kerk\%20van\%20die\%20toekoms\%20en\%20die\%20toekoms\%20van\%20die\%20kerk. pdf.

Humphries-Brooks, S. (2001) The Canaanite Women in Matthew. (Levine 2001:BI.138-156).

Isherwood, L., Stuart, E. (1998) Introducing Body Theology. Sheffield Academic Press, Sheffield, VK.

Jenkins, P. (2002) The Next Christendom: The Coming of Global Christianity. Oxford University Press, New York.

Johnson, L.T. (2004a) Gender in the Letter of James: A Surprising Witness. (Levine 2004:BI.103-113).

Johnson, L.T. (2004b) Making connections: the material expression of friendship in the New Testament. Interpretation 58 no 2 Ap 2004, p 158-171.

Jordan, M.D., Sweeney, M.T., Mellott, D.M. (Eds) (2006) Authorizing Marriage? Canon, Tradition, and Critique in the Blessing of Same-Sex Unions. Princeton University Press, Princeton.

Kanyoro, M.R.A. (1996) God Calls to Ministry: An Inclusive Hospitality. (Kanyoro \& Njoroge 1996:Bl.149162).

Kanyoro, M.R.A., Njoroge, N.J. (Eds) (1996) Groaning in Faith: African Women in the Household of God. Acton Publishers, Nairobi, Kenia.

Kistemaker, S.J. (1986) New Testament Commentary: Exposition of the Epistle of James and the Epistles of John. Baker Bookhouse, Grand Rapids, Michigan.

Kotzé, P.P.A. (1990) Die brief van Jakobus. Lux Verbi, Kaapstad.

Lemmer, J. (2005) Identity \& sexual Identity. Sexology S.A., Pretoria. 
Levine, A. (Ed.) (2001) A Feminist Companion to Matthew. Sheffield Academic Press, London.

Levine, A. (Ed) (2004) The Catholic Epistles and Hebrews. The Pilgrims Press, Cleveland.

Malina, B.J. (1993) The New Testament World. Insights from Cultural Anthropology. Revised Edition. Westminister /John Knox Press, Louisville, Kentucky.

Malina, B.J., Joubert, S., Van der Watt, J. (1995) Vensters wat die Woord laat oopgaan. Orion Uitgewers, Halfway House.

Martin, D.B. (2006) Familiar Idolatry and the Christian Case against Mariage. (Jordan, Sweeney \& Mellott 2006:BI.17-40).

Martin, R.P. (1988) Word Biblical Commentary, Volume 48: James. Word Books, Waco, Texas, VSA.

McFague, S. (1987) Models of God: Theology for an Ecological Nuclear Age. SCM Press, London.

McFague, S. (1993) The Body of God: An Ecological Theology. SCM Press, London.

Mead, L.B. (1994) Transforming Congregations for the Future, An Alban Institute Publication, Once and Future Church Series. The Alban Institute, VSA.

Moo, D.J. (2002) James. (Arnold 2002:Bl.86-119).

Moxnes, H. (2003) Putting Jesus in His Place: A Radical Vision of Household and Kingdom. Westminster John Knox Press, Louisville, Kentucky.

Nakawombe, J.K. (1996) Women in the Kingdom of God. (Kanyoro \& Njoroge 1996:BI.23-30).

Ng, E.Y.L. (2003) Father-God language and Old Testament allusions in James. Tyndale Bulletin 54 (2): 41-54.

O'Day, R. (2004) Jesus as friend in the gospel of John. Interpretation 58 (2): 144-157.

Painter, J. (1999) Just James. The Brother of Jesus in History and Tradition. Fortress Press, Minneapolis, VSA.

Pieterse, H. (1993) Praktiese Teologie as Kommunikatiewe Handelingsteorie. RGN-studies in Praktiese Teologie.

Punt, J. (2005) Queer theory, Postcolonial theory, and biblical interpretation: A preliminary exploration of some intersections. University of Stellenboch. (Forthcoming in Semeia Studies).

Radford Ruether, R. (1989) The Western Tradition and Violence Against Women. (Carlson Brown \& Bohn 1989:BI.31-41).

Radford Ruether, R. (2003) Ecofeminism. (Soskice \& Lipton 2003: BI.23-33).

Rhoads, D.M. (1998) The Letter of James : Friend of God. Currents in Theology and Mission 25 (6 D): $473-$ 486.

Russel, L.M. (1987) Household of freedom: Authority in feminist theology. Philidephia, Westminister.

Sawyer, D. (1996) The Church: Equality or Patriarchy? (Coslett et al 1996:BI.58-68).

Scaer, D.P. (1983) JAMES the apostle of FAITH: A primary Christological Epistle for the Persecuted Church. Concordia Publishing house, St Louis.

Schüssler Fiorenza, E. (Ed) (1994) Searching the Scriptures, Volume Two: A Feminist Commentary.The Crossroad Publishing Company, New York.

Soskice, J.M., Lipton, D. (Eds) (2003) Oxford Readings in Feminism: Feminism \& Theology. Oxford University Press, New York.

Stuart, E. (1997) Prophets, patriarchs and pains in the neck: the Bible. (Stuart 1997:BI.37-46).

Stuart, E. (Ed) (1997) Religion is a Queer Thing: A Guide to the Christian Faith for Lesbian, Gay, Bisexual and Transgendered People. Cassell, London.

Tamez, E. (1994) James. (Schüssler Fiorenza 1994:BI.381-391).

Tamez, E. (2002) The Scandalous Message of James: Faith Without Works is dead. Revised Edition. The Crossroad Publishing Company, New York.

Theissen, G. (2003) Fortress Introduction to the New Testament. Fortress Press, Minneapolis.

UNFPA (United Nations Population Fund) (1999) Women and Armed Conflict: Critical Area No.5. Afgelaai van die internet 19 Mei 2008. http://www.unfpa.org/ intercenter/beijing/armed.htm.

UN-INSTRAW (United Nations International Research and Training Institute for the Advancement of Women) (2008) HIV/AIDS: women and migration in Southern Africa. Berig vir UN-INSTRAW op 31 Julie 2008. Afgelaai van die internet 30 November 2008. http://www.un-instraw.org/en/media-center/enews/hiv-aids-women-and-migration-in-southern-africa.html.

Verseput, D. (2000) Genre and Story: The Community Setting of the Epistle of James. Catholic Biblical Quarterly 62 (1): 96-110.

Wachob, W.H. (2000) The voice of Jesus in the social rhetoric of James. Cambridge University Press, VSA. 
http://ngtt.journals.ac.za

Wolmarans, J.L.P. (1994) Male and Female sexual imagery: James 1:14-15,18. Acta Patristica et Byzantina, (5).

Woodhead, L. (2003) God, Gender and Identity. (Campbell 2003:BI.84-104).

\section{TREFWOORDE}

Ekofeminisme

Huishouding

Patriargie

Gender

Gasvryheid

Jakobus

\section{KEY WORDS}

Eco feminism

Household

Patriargalism

Gender

Hospitality

James

Dr C. Bekker

Frangipanistr.14, Kleinbron Estate, Brackenfell

christelle@iburst.co.za

Tel. 0832669659

Prof J. Punt

Fakulteit Teologie

Universiteit van Stellenbosch

jpunt@sun.ac.za 